\title{
Piscibacillus halophilus sp. nov., a moderately halophilic bacterium from a hypersaline Iranian lake
}

Correspondence

A. Ventosa

ventosa@us.es

\author{
M. A. Amoozegar, ${ }^{1}$ C. Sánchez-Porro, ${ }^{2}$ R. Rohban, ${ }^{3}$ M. Hajighasemi ${ }^{1}$ \\ and A. Ventosa ${ }^{2}$
}
${ }^{1}$ Extremophiles Lab., Department of Microbiology, Faculty of Biology, College of Science, University of Tehran, Tehran, Iran
${ }^{2}$ Department of Microbiology and Parasitology, Faculty of Pharmacy, University of Sevilla, 41012 Sevilla, Spain
${ }^{3}$ Department of Biology, Islamic Azad University, Science and Research Campus, Tehran, Iran

The genus Piscibacillus was proposed by Tanasupawat et al. (2007) to accommodate a moderately halophilic bacterium isolated from fermented fish (pla-ra) in Thailand. The only recognized species of the genus is Piscibacillus salipiscarius. Cells of $P$. salipiscarius are Gram-positive, motile rods that produce oval endospores at terminal positions in swollen sporangia. It is a moderately halophilic bacterium that is able to grow at $2-30 \%(\mathrm{w} / \mathrm{v}) \mathrm{NaCl}$, with optimal growth at $10-20 \%(\mathrm{w} / \mathrm{v}) \mathrm{NaCl}$. This species contains meso-diaminopimelic acid in the cell-wall peptidoglycan, menaquinone with seven isoprene units (MK-7), and phosphatidylglycerol and diphosphatidylglycerol as polar lipids. Its major

The GenBank/EMBL/DDBJ accession number for the 16S rRNA gene sequence of strain $\mathrm{HS} 24^{\top}$ is FM864227.

Neighbour-joining and maximum-likelihood phylogenetic trees, based on 16S rRNA gene sequences, showing the position of strain HS224 among related species, and a table giving the cellular fatty acid profiles of strain $\mathrm{HS} 224^{\top}$ and Piscibacillus salipiscarius RBU $1-1^{\top}$ are available as supplementary material with the online version of this paper. cellular fatty acids are iso- $\mathrm{C}_{15: 0}$ and anteiso- $\mathrm{C}_{15: 0}$ and the DNA G $+\mathrm{C}$ content is $36.7 \mathrm{~mol} \%$. Phylogenetically, $P$. salipiscarius is a member of the family Bacillaceae, within a cluster including species of the genera Aquisalibacillus, Filobacillus and Tenuibacillus. These genera are currently represented by single species, namely Aquisalibacillus elongatus (Márquez et al., 2008), Filobacillus milosensis (Schlesner et al., 2001) and Tenuibacillus multivorans (Ren \& Zhou, 2005).

In this paper we describe the isolation, and phenotypic, chemotaxonomic, phylogenetic and genotypic features of a novel, moderately halophilic bacterium, designated strain $\mathrm{HS} 224^{\mathrm{T}}$, isolated from a hypersaline lake in Iran.

Strain HS224 ${ }^{\mathrm{T}}$ was isolated from water of the hypersaline lake Howz-Soltan, which is located near Qom city in central Iran, during the course of studies focusing on determination of the biodiversity of the lake. This lake covers an area of about 240 and $280 \mathrm{~km}^{2}$ during the dry and wet seasons, respectively. The depth of the salt layer 
that covers almost the entire surface of the playa varies between 20 and $46 \mathrm{~m}$, and the $\mathrm{pH}$ of the water, saline soil and salt sediments differs between 6.5 and 8.2. The major chemical components of the soil, brine, mud and salt are $\mathrm{NaCl}, \mathrm{KCl}, \mathrm{MgSO}_{4}, \mathrm{MgCl}_{2}$ and $\mathrm{Na}_{2} \mathrm{SO}_{4}$. Ions present in the lake water are at the following concentrations: $\mathrm{Na}^{+}$, $8.56 \%$; $\mathrm{Ca}^{2+}, 0.079 \% ; \mathrm{Mg}^{2+}, 4.54 \% ; \mathrm{K}^{+}, 0.056 \%$; $\mathrm{SO}_{4}^{2-}, 0.63 \% ; \mathrm{Cl}^{-}, 16.77 \% ; \mathrm{HCO}_{3}{ }^{-}, 0.022 \% ; \mathrm{Mn}^{2+}$, 1.73 p.p.m.; $\mathrm{Li}^{+}, 2.55$ p.p.m. At the time of sampling, the temperature of the water was $32{ }^{\circ} \mathrm{C}$ and the $\mathrm{pH}$ was 7.6. Strain HS224 $4^{\mathrm{T}}$ was isolated by diluting a water sample in sterile $10 \%(\mathrm{w} / \mathrm{v})$ salt solution, plating on $10 \% \mathrm{HM}$ medium and incubating aerobically at $37{ }^{\circ} \mathrm{C}$. The $10 \%$ $\mathrm{HM}$ medium contained (per litre distilled water): $81 \mathrm{~g}$ $\mathrm{NaCl}, 7 \mathrm{~g} \mathrm{MgCl}_{2}, 9.6 \mathrm{~g} \mathrm{MgSO}_{4}, 0.36 \mathrm{~g} \mathrm{CaCl}_{2}, 2 \mathrm{~g} \mathrm{KCl}$, $0.06 \mathrm{~g} \mathrm{NaHCO}_{3}, 0.026 \mathrm{~g} \mathrm{NaBr}, 5 \mathrm{~g}$ proteose peptone no. 3, $10 \mathrm{~g}$ yeast extract and $1 \mathrm{~g}$ glucose (Ventosa et al., 1982). The $\mathrm{pH}$ of this medium was adjusted to 7.5. The strain was subsequently purified three times by plating on the same medium and was maintained on the same $10 \% \mathrm{HM}$ medium and at $-80{ }^{\circ} \mathrm{C}$ on this medium without agar but supplemented with $30 \%(\mathrm{v} / \mathrm{v})$ glycerol. $P$. salipiscarius JCM $13188^{\mathrm{T}}$ was used as a reference strain and was cultured under the same conditions as strain HS224 ${ }^{\mathrm{T}}$.

Cell morphology was examined by using light microscopy (model CX 31; Olympus) with cells from exponentially growing cultures. Gram staining was performed by using the Burke method (Murray et al., 1994) and the result was confirmed by using the $\mathrm{KOH}$ test (Baron \& Finegold, 1990). The presence of endospores was investigated by using the Schaeffer-Fulton staining method (Murray et al., 1994). Motility was analysed by using the wet-mount method (Murray et al., 1994). To determine the optimal temperature and $\mathrm{pH}$ for growth, broth cultures were incubated at $10-60{ }^{\circ} \mathrm{C}$ at intervals of $5{ }^{\circ} \mathrm{C}$ and at $\mathrm{pH} 5-11$ at intervals of $0.5 \mathrm{pH}$ units. $\mathrm{pH}$ values below $6,6-9$ and above 9 were obtained by using sodium acetate/acetic acid, Tris/HCl and glycine/sodium hydroxide buffers, respectively. Growth at different salt concentrations $(0,2.5,5,7.5$, $10,15,20,25$ and $30 \%$, w/v) was tested on HM medium at $\mathrm{pH}$ 7.5. Growth was monitored based on turbidity at $\mathrm{OD}_{600}$ by using a spectroscopic method (model UV-160 A; Shimadzu). Catalase, oxidase and urease activities, nitrate reduction, hydrolysis of aesculin, production of indole, and methyl red and Voges-Proskauer tests were investigated according to Smibert \& Krieg (1994). Hydrolysis of Tween 80 was examined as described by Harrigan \& McCance (1976). Determination of acid production from carbohydrates, as well as utilization of carbon and nitrogen sources, was performed according to Ventosa et al. (1982). Antibiotic susceptibility tests were performed on Mueller-Hinton agar plus $10 \%(\mathrm{w} / \mathrm{v})$ sea salts (Ventosa et al., 1982) seeded with a bacterial suspension containing $1.5 \times 10^{6}$ c.f.u. $\mathrm{ml}^{-1}$ by using discs (HiMedia) impregnated with various antibiotics. The plates were incubated at $35{ }^{\circ} \mathrm{C}$ for $48 \mathrm{~h}$ and the inhibition zone was interpreted according the manufacturer's manual. Other physiological and biochemical tests were performed as described by Mata et al. (2002), Quesada et al. (1984) and Ventosa et al. (1982).

Strain $\mathrm{HS}_{2} 24^{\mathrm{T}}$ was a Gram-positive, motile rod able to produce oval endospores at terminal positions in swollen sporangia. When grown for 2 days at $35^{\circ} \mathrm{C}$ on $10 \% \mathrm{HM}$ medium, the colonies were circular, entire, smooth, cream and with a diameter of $2 \mathrm{~mm}$. This isolate was moderately halophilic, growing in media containing 1-20\% (w/v) $\mathrm{NaCl}$ and optimally in media containing $10 \%(\mathrm{w} / \mathrm{v})$ $\mathrm{NaCl}$. No growth was observed in the absence of $\mathrm{NaCl}$. Strain $\mathrm{HS}_{224^{\mathrm{T}}}$ grew between $\mathrm{pH} 7.0$ and 10.0, and optimally in media with $\mathrm{pH} 7.5$, and at temperatures ranging from 15 to $55{ }^{\circ} \mathrm{C}$, with optimal growth at $35{ }^{\circ} \mathrm{C}$. Other phenotypic features are included in Table 1 and the species description.

Genomic DNA from strain HS224 ${ }^{\mathrm{T}}$ was prepared according to the method described by Marmur (1961). The 16S rRNA gene was amplified by PCR with the forward primer 16F27 [AGAGTTTGATC(AC)TGGCTCAG] and the reverse primer 16R1488 (CGGTTACCTTGTTAGGACTTCACC). Direct sequence determination of the PCR-amplified DNA was carried out by using an automated DNA sequencer (model ABI 3130XL; Applied Biosystems). 16S rRNA gene sequence analysis was performed with the ARB software package (Ludwig et al., 2004). The $16 \mathrm{~S}$ rRNA gene sequence was aligned with published sequences of closely related bacteria and the alignment was confirmed and checked against both primary and secondary structures of the $16 \mathrm{~S}$ rRNA molecule by using the alignment tool of the ARB software package. Phylogenetic trees were constructed by using the maximum-likelihood (Felsenstein, 1981), maximum-parsimony (Fitch, 1971) and neighbour-joining (Saitou \& Nei, 1987) algorithms integrated within the ARB software for phylogenetic inference. 16S rRNA gene sequences used for phylogenetic comparisons were obtained from the GenBank database and their strain designations and accession numbers are shown in Fig. 1.

An almost-complete 16S rRNA gene sequence (1472 bp) of strain $\mathrm{HS} 224^{\mathrm{T}}$ was obtained and used for initial BLAST searches in GenBank and for phylogenetic analysis. Identification of phylogenetic neighbours and calculation of pairwise $16 \mathrm{~S}$ rRNA gene sequence similarity were achieved by using the EzTaxon server (http://www.eztaxon. org/; Chun et al., 2007). Phylogenetic analysis, based on the maximum-parsimony algorithm, revealed that strain HS224 ${ }^{\mathrm{T}}$ formed a phyletic group with $P$. salipiscarius RBU1-1 ${ }^{\mathrm{T}}$ (Fig. 1), and these two taxa shared $98.5 \% 16 \mathrm{~S}$ rRNA gene sequence similarity. Strain $\mathrm{HS}_{2} 24^{\mathrm{T}}$ was also related closely to the type strains of A. elongatus ( $98.0 \%$ $16 \mathrm{~S}$ rRNA gene sequence similarity), F. milosensis (97.9\%) and T. multivorans $(97.0 \%)$. The neighbour-joining (Supplementary Fig. S1, available in IJSEM Online) and maximum-likelihood (Supplementary Fig. S2) methods resulted in highly similar tree topologies, confirming the phylogenetic cluster formed by strain $\mathrm{HS}_{22} 24^{\mathrm{T}}$ and $P$. salipiscarius RBU1-1 ${ }^{\mathrm{T}}$. 
Table 1. Characteristics that differentiate strain $\mathrm{HS} 224^{\top}$ from $P$. salipiscarius and other closely related species

Taxa: 1, strain HS224 ${ }^{\mathrm{T}}$; 2, P. salipiscarius RBU1-1 ${ }^{\mathrm{T}}$ (data from Tanasupawat et al., 2007); 3, A. elongatus SH4s ${ }^{\mathrm{T}}$ (Márquez et al., 2008); 4, F. milosensis SH $714^{\mathrm{T}}$ (Schlesner et al., 2001); 5, T. multivorans (Ren \& Zhou, 2005). +, Positive; -, negative; w, weakly positive; ND, no data available.

\begin{tabular}{|c|c|c|c|c|c|}
\hline Characteristic & 1 & 2 & 3 & 4 & 5 \\
\hline Cell size $(\mu \mathrm{m})$ & $0.5-0.7 \times 2.5-4.0$ & $0.4-0.5 \times 1.5-4.0$ & $0.5 \times 2.0-10.0$ & $0.3-0.4 \times 3.0-7.0$ & $0.3-0.5 \times 2.0-6.0$ \\
\hline Oxidase & + & + & - & - & + \\
\hline Spore shape & $\begin{array}{l}\text { Oval, terminal in } \\
\text { swollen sporangia }\end{array}$ & $\begin{array}{l}\text { Oval, terminal in } \\
\text { swollen sporangia }\end{array}$ & - & $\begin{array}{l}\text { Spherical, terminal in } \\
\text { swollen sporangia }\end{array}$ & $\begin{array}{l}\text { Spherical, terminal in } \\
\text { swollen sporangia }\end{array}$ \\
\hline Motility & + & + & - & + & - \\
\hline $\begin{array}{l}\text { Temperature range } \\
\text { (optimum) }\left({ }^{\circ} \mathrm{C}\right)\end{array}$ & $15-55(35)$ & $15-48(37)$ & $20-55(37)$ & $\mathrm{ND}-42(33-38)$ & $21-42(36-41)$ \\
\hline $\mathrm{pH}$ range (optimum) & $7.0-10.0(7.5)$ & $5.0-9.0(7)$ & $7.0-10.0(7.5)$ & $6.5-8.9(7.3-7.8)$ & $6.5-9.0(7.0-8.0)$ \\
\hline \multicolumn{6}{|l|}{ Acid production from: } \\
\hline Galactose & - & + & ND & - & - \\
\hline \multicolumn{6}{|l|}{ Hydrolysis of: } \\
\hline Aesculin & + & ND & - & - & + \\
\hline Starch & - & + & - & - & - \\
\hline Casein & + & + & - & - & + \\
\hline Gelatin & + & + & - & - & + \\
\hline Tween 80 & + & - & - & ND & - \\
\hline DNase & - & + & $\mathrm{ND}$ & + & $\mathrm{ND}$ \\
\hline Peptidoglycan type/variant & A $1 \gamma / m e s o-D A P *$ & A $1 \gamma /$ meso-DAP & A4 $\beta /$ Orn-D-Asp & A4 $\beta /$ Orn-D-Glu & A $1 \gamma / m e s o-D A P$ \\
\hline DNA G $+\mathrm{C}$ content $(\mathrm{mol} \%)$ & 37.5 & 36.7 & 45.9 & 35.0 & $36.5-37.0$ \\
\hline
\end{tabular}

*meso-DAP, meso-diaminopimelic acid.

The $\mathrm{G}+\mathrm{C}$ content of the genomic DNA was determined from the midpoint value of the thermal denaturation profile (Marmur \& Doty, 1962) by using the equation of Owen \& Hill (1979), as previously described in detail (Ventosa et al., 1999). The G +C content of the DNA of strain HS224 ${ }^{\mathrm{T}}$ was $37.5 \mathrm{~mol} \%$, very similar to that reported for the type strain of $P$. salipiscarius (Tanasupawat et al., 2007) as well as for other closely related species except $A$. elongatus (Márquez et al., 2008) (Table 1).

DNA-DNA hybridization studies were performed by using the competition procedure of the membrane method (Johnson, 1994), as described in detail by Arahal et al. (2001a, b). The hybridization temperature used was $46.3{ }^{\circ} \mathrm{C}$, which is within the limit of validity for the filter method (De Ley \& Tijtgat, 1970) and the percentage DNA-DNA relatedness was calculated according to Johnson (1994). Experiments were carried out in triplicate. The level of DNA-DNA relatedness between strain HS224 $4^{\mathrm{T}}$ and P. salipiscarius JCM $13188^{\mathrm{T}}$ was $30.8 \%$, well below the $70 \%$ cut-off generally accepted for species delineation (Stackebrandt \& Goebel, 1994; Stackebrandt et al., 2002).
Analysis of polar lipids, quinones and peptidoglycan of the cell wall was carried out by the Identification Service of the DSMZ and Dr B. J. Tindall, DSMZ, Braunschweig, Germany. Major polar lipids were phosphatidylglycerol and diphosphatidylglycerol; two phospholipids were detected as minor components. Strain HS224 ${ }^{\mathrm{T}}$ contained MK-7 as the unique menaquinone and a cell-wall peptidoglycan type A1 $\gamma$, with meso-diaminopimelic acid as the diagnostic diamino acid. These features are the same as those reported for $P$. salipiscarius (Tanasupawat et al., 2007). However, these two taxa can be distinguished from species of other closely related genera based on peptidoglycan type: the cell wall of $A$. elongatus contains peptidoglycan of the A4 $\beta$ type, with L-Orn as the diamino acid and D-Asp as the dicarboxylic amino acid present in the cross-linkage (Márquez et al., 2008), and F. milosensis also has peptidoglycan of the A4 $\beta$ type, but with DGlu in the cross-linkage (Schlesner et al., 2001).

Fatty acid analysis was performed by using the MIDI system (Microbial Identification System). Cells were cultured on marine agar 2216 (Difco) containing $10 \%$ $(\mathrm{w} / \mathrm{v}) \mathrm{NaCl}$ at $37{ }^{\circ} \mathrm{C}$ for $24 \mathrm{~h}$. Extraction and analysis were performed according to the recommendations of the MIDI 




Fig. 1. Maximum-parsimony phylogenetic tree, based on 16S rRNA gene sequence comparisons, showing the relationship of strain $\mathrm{HS} 224^{\top}$ with related species. Accession numbers of the sequences used in this study are given in parentheses. Bacillus licheniformis DSM $13^{\top}$ was used as an outgroup. Bootstrap percentages (based on 1000 replicates) of $>50 \%$ are shown at branch points. Bar, 0.01 substitutions per nucleotide position.

system. This analysis was carried out by the Identification, Characterization and Molecular Typing Service of the $\mathrm{BCCM}^{\mathrm{TM}} / \mathrm{LMG}$ bacterial collection (Gent, Belgium). The cellular fatty acid profile of strain $\mathrm{HS} 224^{\mathrm{T}}$ was characterized by anteiso- $\mathrm{C}_{15: 0}\left(35.3 \%\right.$ of the total), iso- $\mathrm{C}_{15: 0}$ $(26.3 \%)$, anteiso- $\mathrm{C}_{17: 0}(13.8 \%)$ and iso- $\mathrm{C}_{16: 0}(9.4 \%)$ as major components; iso- $\mathrm{C}_{17: 0}(5.8 \%)$, iso- $\mathrm{C}_{14: 0}(2.6 \%)$, $\mathrm{C}_{16: 1} \omega 7 c(2.5 \%), \mathrm{C}_{16: 0}(1.4 \%), \mathrm{C}_{16: 1} \omega 11 c(0.5 \%)$ and summed feature 4 (iso- $\mathrm{C}_{17: 1}$ and/or anteiso- $\mathrm{C}_{17: 1} ; 1.3 \%$ ) were detected as minor components. This profile is similar to that reported for P. salipiscarius (Supplementary Table S1, available in IJSEM Online), which also contained anteiso- $\mathrm{C}_{15: 0}$, iso- $\mathrm{C}_{15: 0}$, anteiso- $\mathrm{C}_{17: 0}$ and iso- $\mathrm{C}_{16: 0}$ as major fatty acids (Tanasupawat et al., 2007).

The characteristics that can be used to differentiate between strain HS224 ${ }^{\mathrm{T}}$ and P. salipiscarius and other related species are summarized in Table 1 . The results show clearly that strain HS224 ${ }^{\mathrm{T}}$ is related closely to P. salipiscarius but can be differentiated based on several phenotypic and chemotaxonomic features. DNA-DNA hybridization data support the placement of strain $\mathrm{HS} 224^{\mathrm{T}}$ as a member of species distinct from $P$. salipiscarius. On the basis of the data obtained from this polyphasic taxonomy study, we suggest that strain HS224 ${ }^{\mathrm{T}}$ represents a novel species of the genus Piscibacillus, for which the name Piscibacillus halophilus sp. nov. is proposed.

\section{Description of Piscibacillus halophilus sp. nov.}

Piscibacillus halophilus (ha.lo.phi'lus. Gr. n. hals, halos salt; Gr. adj. philos loving; N.L. masc. adj. halophilus salt-loving).
Cells are Gram-positive, motile rods $(0.5-0.7 \times 2.5-$ $4.0 \mu \mathrm{m})$. Cells produce oval endospores terminally positioned within swollen sporangia. Colonies are circular, entire, smooth, cream in colour and $2 \mathrm{~mm}$ in diameter on $10 \% \mathrm{HM}$ agar medium after $48 \mathrm{~h}$ incubation at $35{ }^{\circ} \mathrm{C}$. Facultatively anaerobic. Moderately halophilic. The optimum $\mathrm{NaCl}$ concentration for growth is $10 \%(\mathrm{w} / \mathrm{v})$, with a range of $1-20 \%(\mathrm{w} / \mathrm{v}) \mathrm{NaCl}$ for growth. No growth occurs in the absence of $\mathrm{NaCl}$. Growth is observed at 15$55{ }^{\circ} \mathrm{C}$ (optimum at $35{ }^{\circ} \mathrm{C}$ ) and at $\mathrm{pH}$ 7.0-10.0 (optimum at $\mathrm{pH}$ 7.5). Catalase- and oxidase-positive. Indole and $\mathrm{H}_{2} \mathrm{~S}$ are not produced. Gelatin, casein, aesculin, and Tweens 20, 40, 60 and 80 are hydrolysed. Starch and DNA are not hydrolysed. Nitrate is not reduced to nitrite. Acid is not produced from D-glucose, D-fructose, galactose, lactose, maltose, melibiose, D-mannose, trehalose, D-xylose or myoinositol. Methyl red, Voges-Proskauer, urease, $\beta$-galactosidase, lysine and ornithine decarboxylase, arginine dihydrolase and phenylalanine deaminase tests are negative. The following compounds are not utilized as sole source of carbon and energy: D-fructose, galactose, D-glucose, lactose, maltose, D-mannose, melibiose, D-ribose, sucrose, glycerol, myo-inositol, alanine, arginine, asparagine, cysteine, glycine, leucine, lysine, methionine, proline and valine. Sensitive to carbenicillin $(100 \mu \mathrm{g})$, nitrofurantoin $(300 \mu \mathrm{g})$, tetracycline $(30 \mu \mathrm{g})$ and rifampicin $(5 \mu \mathrm{g})$. Resistant to amoxicillin $(30 \mu \mathrm{g})$, gentamicin $(30 \mu \mathrm{g})$, tobramycin $(10 \mu \mathrm{g})$, kanamycin $(30 \mu \mathrm{g})$ and polymyxin $\mathrm{B}$ (100 U). Polar lipids are phosphatidylglycerol and diphosphatidylglycerol as well as two minor phospholipids. The isoprenoid quinone is MK-7. The peptidoglycan type is 
A1 $\gamma$, with meso-diaminopimelic acid as the diagnostic diamino acid. Cellular fatty acids are anteiso- $\mathrm{C}_{15: 0}$, iso- $\mathrm{C}_{15: 0}$, anteiso- $\mathrm{C}_{17: 0}$, iso- $\mathrm{C}_{16: 0}$, iso- $\mathrm{C}_{17: 0}$, iso- $\mathrm{C}_{14: 0}$, $\mathrm{C}_{16: 1} \omega 7 c, \mathrm{C}_{16: 0}, \mathrm{C}_{16: 1} \omega 11 c$ and summed feature 4 (iso$\mathrm{C}_{17: 1}$ and/or anteiso- $\mathrm{C}_{17: 1}$ ). The DNA G $+\mathrm{C}$ content of the type strain is $37.5 \mathrm{~mol} \%\left(T_{\mathrm{m}}\right)$.

The type strain, HS224 ${ }^{\mathrm{T}}\left(=\mathrm{CCM} 7596^{\mathrm{T}}=\right.$ DSM $21633^{\mathrm{T}}=$ JCM $15721^{\mathrm{T}}=$ LMG $\left.24786^{\mathrm{T}}\right)$, was isolated from the hypersaline lake Howz-Soltan in Iran.

\section{Acknowledgements}

We thank J. Euzéby for his help with etymology. This study was supported by grants from the Iranian Environment Department (3/42274), the Spanish Ministerio de Educación y Ciencia (BIO200606927) and Junta de Andalucía (P06-CVI-01829).

\section{References}

Arahal, D. R., García, M. T., Ludwig, W., Schleifer, K. H. \& Ventosa, A. (2001a). Transfer of Halomonas canadensis and Halomonas israelensis to the genus Chromohalobacter, as Chromohalobacter canadensis comb. nov. and Chromohalobacter israelensis comb. nov. Int J Syst Evol Microbiol 51, 1443-1448.

Arahal, D. R., Garcia, M. T., Vargas, C., Cánovas, D., Nieto, J. J. \& Ventosa, A. (2001b). Chromohalobacter salexigens sp. nov., a moderately halophilic species that includes Halomonas elongata DSM 3043 and ATCC 33174. Int J Syst Evol Microbiol 51, 1457-1462.

Baron, E. J. \& Finegold, S. M. (1990). Bailey and Scott's Diagnostic Microbiology, 8th edn. St Louis: Mosby.

Chun, J., Lee, J.-H., Jung, Y., Kim, M., Kim, S., Kim, B. K. \& Lim, Y.-W. (2007). EzTaxon: a web-based tool for the identification of prokaryotes based on $16 \mathrm{~S}$ ribosomal RNA gene sequences. Int J Syst Evol Microbiol 57, 2259-2261.

De Ley, J. \& Tijtgat, R. (1970). Evaluation of membrane filter methods for DNA-DNA hybridization. Antonie van Leeuwenhoek 36, 461-474.

Felsenstein, J. (1981). Evolutionary trees from DNA sequences: a maximum likelihood approach. J Mol Evol 17, 368-376.

Fitch, W. M. (1971). Toward defining the course of evolution: minimum change for a specific tree topology. Syst Zool 20, 406-416.

Harrigan, W. F. \& McCance, M. E. (1976). Laboratory Methods in Food and Dairy Microbiology. London: Academic Press.

Johnson, J. L. (1994). Similarity analysis of DNAs. In Methods for General and Molecular Bacteriology, pp. 655-681. Edited by P. Gerhardt, R. G. E. Murray, W. A. Wood \& N. R. Krieg. Washington, DC: American Society for Microbiology.

Ludwig, W., Strunk, O., Westram, R., Richter, L., Meier, H., Yadhukumar, Buchner, A., Lai, T., Steppi, S. \& other authors (2004). ARB: a software environment for sequence data. Nucleic Acids Res 32, 1363-1371.

Marmur, J. (1961). A procedure for the isolation of deoxyribonucleic acid from microorganisms. J Mol Biol 3, 208-218.
Marmur, J. \& Doty, P. (1962). Determination of the base composition of deoxyribonucleic acid from its thermal denaturation temperature. J Mol Biol 5, 109-118.

Márquez, M. C., Carrasco, I. J., Xue, Y., Ma, Y., Cowan, D. A., Jones, B. E., Grant, W. D. \& Ventosa, A. (2008). Aquisalibacillus elongatus gen. nov., sp. nov., a moderately halophilic bacterium of the family Bacillaceae isolated from a saline lake. Int J Syst Evol Microbiol 58, 1922-1926.

Mata, J. A., Martinez-Canovas, J., Quesada, E. \& Bejar, V. (2002). A detailed phenotypic characterization of the type strains of Halomonas species. Syst Appl Microbiol 25, 360-375.

Murray, R. G. E., Doetsch, R. N. \& Robinow, C. F. (1994). Determinative and cytological light microscopy. In Methods for General and Molecular Bacteriology, pp. 21-41. Edited by P. Gerhardt, R. G. E. Murray, W. A. Wood \& N. R. Krieg. Washington, DC: American Society for Microbiology.

Owen, R. J. \& Hill, L. R. (1979). The estimation of base compositions, base pairing and genome size of bacterial deoxyribonucleic acids. In Identification Methods for Microbiologists, 2nd edn, pp. 217-296. Edited by F. A. Skinner \& D. W. Lovelock. London: Academic Press.

Quesada, E., Ventosa, A., Ruiz-Berraquero, F. \& Ramos-Cormenzana, A. (1984). Deleya halophila, a new species of moderately halophilic bacteria. Int J Syst Bacteriol 34, 287-292.

Ren, P. G. \& Zhou, P. J. (2005). Tenuibacillus multivorans gen. nov., sp. nov., a moderately halophilic bacterium isolated from saline soil in Xin-Jiang, China. Int J Syst Evol Microbiol 55, 95-99.

Saitou, N. \& Nei, M. (1987). The neighbor-joining method: a new method for reconstructing phylogenetic trees. Mol Biol Evol 4, 406-425.

Schlesner, H., Lawson, P. A., Collins, M. D., Weiss, N., Wehmeyer, U., Völker, H. \& Thomm, M. (2001). Filobacillus milensis gen. nov., sp. nov., a new halophilic spore-forming bacterium with Orn-D-Glu-type peptidoglycan. Int J Syst Evol Microbiol 51, 425-431.

Smibert, R. M. \& Krieg, N. R. (1994). Phenotypic characterization. In Methods for General and Molecular Bacteriology, pp. 607-654. Edited by P. Gerhardt, R. G. E. Murray, W. A. Wood \& N. R. Krieg. Washington, DC: American Society for Microbiology.

Stackebrandt, E. \& Goebel, B. M. (1994). Taxonomic note: a place for DNA-DNA reassociation and $16 \mathrm{~S}$ rRNA sequence analysis in the present species definition in bacteriology. Int J Syst Bacteriol 44, 846-849.

Stackebrandt, E., Fredericksen, W., Garrity, G. M., Grimont, P. A. D., Kämpfer, P., Maiden, M. C. J., Nesme, X., Rosselló-Mora, R., Swings, J. \& other authors (2002). Report of the ad hoc committee for the re-evaluation of the species definition in bacteriology. Int $J$ Syst Evol Microbiol 52, 1043-1047.

Tanasupawat, S., Namwong, S., Kudo, T. \& Itoh, T. (2007). Piscibacillus salipiscarius gen. nov., sp. nov., a moderately halophilic bacterium from fermented fish (pla-ra) in Thailand. Int J Syst Evol Microbiol 57, 1413-1417.

Ventosa, A., Quesada, E., Rodriguez-Valera, F., Ruiz-Berraquero, F. \& Ramos-Cormenzana, A. (1982). Numerical taxonomy of moderately halophilic Gram-negative rods. J Gen Microbiol 128, 1959-1968.

Ventosa, A., Gutierrez, M. C., Kamekura, M. \& Dyall-Smith, M. L. (1999). Proposal to transfer Halococcus turkmenicus, Halobacterium trapanicum JCM 9743 and strain GSL-11 to Haloterrigena turkmenica gen. nov., comb. nov. Int J Syst Bacteriol 49, 131-136. 